\title{
Plasma Serine Protease Inhibitor
}

National Cancer Institute

\section{Source}

National Cancer Institute. Plasma Serine Protease Inhibitor. NCI Thesaurus. Code

C17324.

Plasma serine protease inhibitor ( $406 \mathrm{aa}, \sim 46 \mathrm{kDa}$ ) is encoded by the human SERPINA5 gene. This protein is involved in the regulation of serine proteinases, spermatogenesis and fusion of sperm with the plasma membrane of an egg. 